\title{
Groundwater recharge by high-salinity lake water in a density-driven flow dominated system: an isotopic approach
}

\author{
Nicolás Valiente ${ }^{1}$, David Sanz ${ }^{1}$, and Juan José Gómez-Alday,"* \\ ${ }^{1}$ Biotechnology and Natural Resources Section, Institute for Regional Development (IDR), University \\ of Castilla-La Mancha (UCLM), Campus Universitario s/n, 02071 Albacete, Spain
}

\begin{abstract}
Pétrola Lake is a terminal lake located in the discharge zone of an endorheic basin. Terminal lakes may be responsible for a significant amount of recharge from evaporated saline water, increasing the salinity of the shallow groundwater. The purpose of this paper is to evaluate the interaction between groundwater and saline water from Pétrola Lake in order to improve the knowledge of groundwater recharge processes by density-driven flow (DDF) in terminal lakes. To achieve this goal, hydrochemical (chloride concentration) and stable isotope $\left(\delta^{18} \mathrm{O}\right.$ and $\left.\delta \mathrm{D}_{\mathrm{H} 2 \mathrm{O}}\right)$ data were used. The isotopic composition of 190 groundwater and surface water samples collected between September 2008 and July 2015 provide a regression line $\left(\delta \mathrm{D}_{\mathrm{H} 2 \mathrm{O}}=5.0 \cdot \delta^{18} \mathrm{O}-14.3 \%, \mathrm{R}^{2}=0.95\right)$ consistent with dominant evaporation processes. In the basin, groundwater recharge is mainly produced by Atlantic-derived precipitation. In the lake, isotope data suggested that the loss of water occurred at humidity values between $60 \%$ and $75 \%$. The saline boundary layer is formed at elevated salt concentrations. Leakage from the lake to the underlying aquifer would take place with salinities from $1.24 \mathrm{~g} / \mathrm{cm}^{3}$ by means of the DDF. This study contributes to better understand the role of DDF in terminal lakes.
\end{abstract}

\section{Introduction}

The volume of inland saline waters in the world is estimated to be around $85,400 \mathrm{~km}^{3}$ [1]. Saline lakes are common features of arid and semi-arid regions, where the excess of evaporation over precipitation resulted in the accumulation of salts at the land surface. Terminal discharge lakes represent the end-point of groundwater flow systems. In those lakes, water contribution derives from regional groundwater flow (RGF) as well as from perimeter recharge areas. These terminal lakes may be responsible for a significant amount of recharge from evaporated saline water, increasing the salinity of the shallow groundwater [2]. Groundwater recharge is produced by the wedge-shaped high salinity zone, which is formed underneath a terminal hypersaline lake. High salinity zones can be expanded laterally and vertically, controlled partially by groundwater inflow [3]. Solutes transported by the density-driven flow (DDF) can be mixed in the freshwater-saltwater

*Corresponding author: JuanJose.Gomez@uclm.es 
interface, where they can exert an important role in the natural attenuation of pollutants [4]. Documenting surface-water/groundwater interaction in saline lakes is essential to know how the transport of solutes occurs.

Stable isotopes of the water molecule $\left(\delta^{18} \mathrm{O}_{\mathrm{H} 2 \mathrm{O}}\right.$ and $\left.\delta \mathrm{D}_{\mathrm{H} 2 \mathrm{O}}\right)$ have been widely used as tracers to provide information about hydrogeological processes. In lakes, the isotopic composition of surface water is closely connected to climate, reflecting meteorological conditions of the region, but also to the balance between inputs and outputs. The goal of this study was to identify the source of groundwater recharge in the Pétrola Lake. This lake is a terminal lake located in La Mancha region (High Segura Basin, SE Spain), an important area of distribution of saline lakes in the Iberian Peninsula.

The anthropogenic pressure over this saline wetland, mainly related to agriculture and wastewater [5], is able to alter the functioning of the natural saline system by modifying the mass balance and the intensity of biogeochemical processes. Thus, the situation of Pétrola Basin is well suited to use a combined approach of stable isotopes $\left(\delta^{18} \mathrm{O}_{\mathrm{H} 2 \mathrm{O}}\right.$ and $\left.\delta \mathrm{D}_{\mathrm{H} 2 \mathrm{O}}\right)$ and hydrochemical data $\left(\mathrm{Cl}^{-}\right.$concentration). The aim of this study was to evaluate the interaction between groundwater and saline water from Pétrola Lake in order to improve the knowledge of groundwater recharge processes by DDF in terminal lakes.

\section{Material and methods}

\subsection{Study area}

Pétrola endorheic basin $\left(43 \mathrm{~km}^{2}\right)$ hosts an unconfined detrital aquifer in which the saline lake occupies the topographic lowest position. Pétrola Lake has an extension of about 1.76 $\mathrm{km}^{2}$, whose depth nowhere exceeds 2 meters [6]. Seasonal fluctuations in water volume are found as a response to climatic events. The study area is characterized by irregular rainfall periods, alternating long episodes of drought and torrential precipitations. Maximum water volume stored in the lake is found at early spring (about $0.90 \mathrm{hm}^{3}$ ), in agreement with abundant precipitation and low evaporation rates. Minimum volume or completely dryness can be observed at the end of summer, associated to few precipitation events and maximum evaporation rates, which causes an increase in the concentration of salts in the lake. There are important density contrasts between the hypersaline water of the lake (up to $1.3 \mathrm{~g} / \mathrm{cm}^{3}$ ) and freshwater from the aquifer $\left(\approx 1 \mathrm{~g} / \mathrm{cm}^{3}\right)$. A buoyancy DDF from the lake towards the underlying aquifer is found in the saline lake-aquifer interface as a result of the instability of the saline boundary layer [4-6].

The aquifer is composed mostly of terrigenous and carbonate units whose thickness can exceed $60 \mathrm{~m}$ ranging in age from Barremian to Albian. Albian deposits (Utrillas Facies) consist of siliciclastic sands, sandy-conglomerates, and reddish to dark-gray clay to argillaceous sediments deposited over Aptian sediments (Figure 1). The Utrillas Facies materials comprise sandy-conglomerate sediments interstratified by gray-to-black argillaceous sediments. The hydraulic conductivity of these materials is low (1-10 m/day). However, they present a high storage capacity (30-40\%). The impermeable bottom is constituted by the clayey materials of the base of the Cretaceous sequence (Weald facies). The groundwater flow is radial and centripetal from the recharge areas (system boundaries) to the Pétrola Lake that occupies the terminal discharge zone of the basin. Horizontal head gradients are between $10^{-3}$ and $10^{-2}$. Vertical head gradients across the area are generally downward, except for the vicinity of the lake, where head gradients are upward. 


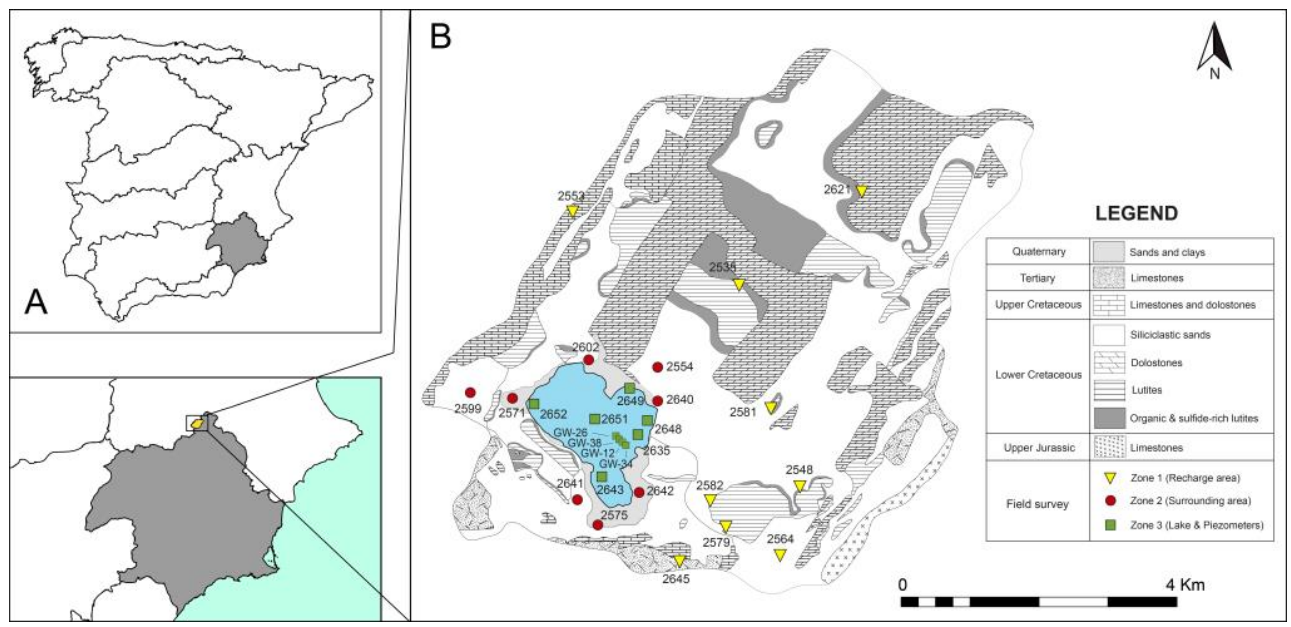

Fig. 1. A) Location of the High Segura Basin in Europe. B) Geological map of Pétrola basin and location of the 27 control points used in this study.

\subsection{Chemical and isotopic analyses}

A total of 190 water samples from 27 control points were collected from springs, surface water (including streams and lake), agricultural wells, and lake piezometers (Figure 1). The piezometers $(\mathrm{n}=4)$ were installed at different depths $(\mathrm{GW}-12$ at $12.1 \mathrm{mbgs}, \mathrm{GW}-26$ at 25.8 mbgs, GW-34 at $34.1 \mathrm{mbgs}$, and GW-38 at $37.9 \mathrm{mbgs}$ ) during 2008 nearby the lake border, as described by [4]. Water samples were collected in two distinct periods. The initial field campaign between September 2008 and October 2011, the methodology and results of which were published by [4]. The second field survey was performed from March 2013 to July 2015, whose methodology and results were published by [5]. Sampling points from the study area have been divided into three groups: Zone 1, Zone 2, and Zone 3. Zone 1 included the recharge area. Zone 2 comprised control points located nearby the lake, following the groundwater flow direction from Zone 1 to the discharge zone. Zone 3 represented the zone of density-driven groundwater flow located under the lake (piezometers) and lake surface waters. Density values were calculated using PHREEQC software [7]. Chloride concentrations in $\mathrm{mmol} / \mathrm{kg}$ were calculated from original concentration (in $\mathrm{mg} / \mathrm{L}$ ) and density values.

\section{Results and discussion}

Chemical and isotopic results are summarized in Table 1. Highest values of electrical conductivity (EC), total dissolved solids (TDS), density $(\rho)$ and chloride were found in piezometers GW-12 and GW-26. Samples from piezometers belong to the first field campaign (2008-2011), whereas samples from surface lake water also included second field campaign (2013-2015), which included a wet period. Isotope compositions suggested high evaporation rates, showing the most positive mean values of $\delta^{18} \mathrm{O}_{\mathrm{H} 2 \mathrm{O}}(+2.2 \%)$ and $\delta \mathrm{D}_{\mathrm{H} 2 \mathrm{O}}(-$ $2.2 \%$ ) in lake waters. Piezometer GW-38 showed similar chemical and isotopic results than those from recharge and surrounding aquifer areas. Finally, piezometer GW-34 showed the influence of both brine and groundwater from RGF.

The isotopic composition of water samples was used to calculate a regression line $(\delta \mathrm{D}=$ $+5.0 \cdot \delta^{18} \mathrm{O}-14.3 \%$; $\left.\mathrm{R}^{2}=0.95\right)$. This regression line was compared with the Madrid Meteoric Water Line (MaMWL: $\delta \mathrm{D}=+7.6 \cdot \delta^{18} \mathrm{O}+5.4 ; \mathrm{R}^{2}=0.89$ ) and the Murcia Meteoric Water Line (MuMWL: $\delta \mathrm{D}=+6.0 \cdot \delta^{18} \mathrm{O}-2.8 ; \mathrm{R}^{2}=0.85$ ), both calculated using data from 
the International Atomic Energy Agency (IAEA) for the period of 1970 to 2006, considering values whose precipitation was over $20 \mathrm{~mm}(\mathrm{n}=109)$. Pétrola line intersected the MaMWL at $\sim \delta^{18} \mathrm{O}_{\mathrm{H} 2 \mathrm{O}}=-7.8 \%$ and $\delta \mathrm{D}_{\mathrm{H} 2 \mathrm{O}}=-53.8 \%$, values which were subsequently considered for modeling purposes. The deuterium excess (d-value $=\delta \mathrm{D}-8 \cdot \delta^{18} \mathrm{O}$ from [8]) can be employed to recognize the potential source of water vapor [9]. Atlantic origin precipitation was characterized by $\mathrm{d}$-values up to $+10 \%$, in contrast to Mediterraneanderived $(+27 \%)$ [10]. In the recharge area from Pétrola Basin (Zone 1), mean d-value was $+5.8 \%$ o $(n=21)$, suggesting that groundwater recharge in Pétrola Basin is mainly produced by Atlantic-derived precipitation.

Table 1. Chemical and isotopic results in water samples grouped by zones. Rech.: recharge area.

Surr.: surrounding area. EC: electrical conductivity (mS/cm). TDS: total dissolved solids $(\mathrm{g} / \mathrm{L})$. $\rho$ : density $\left(\mathrm{g} / \mathrm{cm}^{3}\right) . \delta^{18} \mathrm{O}_{\mathrm{H} 2 \mathrm{O}}$ and $\delta \mathrm{D}_{\mathrm{H} 2 \mathrm{O}}$ are expressed in \%. $\mathrm{Cl}^{-}$concentration in $\mathrm{mmol} / \mathrm{kg}$.

\begin{tabular}{|c|c|c|c|c|c|c|c|c|}
\hline Group & Zone & $\mathbf{p H}$ & $\mathbf{E C}$ & $\mathbf{T D S}$ & $\mathbf{\rho}$ & $\mathbf{C l}^{-}$ & $\boldsymbol{\delta}^{\mathbf{1 8}} \mathbf{O}_{\text {н20 }}$ & $\boldsymbol{\delta} \mathbf{D}_{\text {H20 }}$ \\
\hline Rech. & 1 & $7.5 \pm 0.2$ & $1.3 \pm 0.3$ & $0.6 \pm 0.2$ & $1.00 \pm 0.00$ & $2.1 \pm 0.9$ & $-6.6 \pm 1.0$ & $-49.0 \pm 3.5$ \\
\hline Surr. & 2 & $8.0 \pm 0.2$ & $1.8 \pm 0.5$ & $0.9 \pm 0.3$ & $1.00 \pm 0.00$ & $4.5 \pm 1.7$ & $-6.0 \pm 1.3$ & $-45.7 \pm 7.0$ \\
\hline Lake & 3 & $8.6 \pm 0.4$ & $38.6 \pm 25.4$ & $22.9 \pm 15.3$ & $1.05 \pm 0.06$ & $478 \pm 714$ & $+2.2 \pm 4.1$ & $-2.2 \pm 20.6$ \\
\hline GW-12 & 3 & $7.0 \pm 0.0$ & $89.0 \pm 6.8$ & $53.2 \pm 4.1$ & $1.09 \pm 0.01$ & $1,157 \pm 193$ & $-2.7 \pm 1.3$ & $-22.1 \pm 4.4$ \\
\hline GW-26 & 3 & $6.9 \pm 0.1$ & $56.5 \pm 11.4$ & $33.7 \pm 6.8$ & $1.05 \pm 0.02$ & $571 \pm 201$ & $-4.7 \pm 1.0$ & $-38.1 \pm 1.8$ \\
\hline GW-34 & 3 & $7.0 \pm 0.1$ & $10.3 \pm 7.3$ & $5.9 \pm 4.4$ & $1.01 \pm 0.00$ & $94.0 \pm 61.0$ & $-5.9 \pm 1.5$ & $-45.4 \pm 3.9$ \\
\hline GW-38 & 3 & $7.3 \pm 0.5$ & $2.4 \pm 0.6$ & $1.2 \pm 0.3$ & $1.00 \pm 0.00$ & $6.5 \pm 2.1$ & $-7.1 \pm 0.9$ & $-49.5 \pm 1.8$ \\
\hline
\end{tabular}

In order to evaluate the loss of water in the lake by means of stable isotope data, the isotopic changes during evaporation of surface water have been modelled following the modified equations of [11]. Those equations constrain the theoretical evolution in the isotopic composition of the residual lake water as a function of the fraction of lake water that has been lost to evaporation. The intersection point of Pétrola line and the MaMWL was used as the initial isotopic composition $(-7.8 \%$ and $-53.8 \%)$. It is assumed that neither inputs nor outputs to the water body other than loss of water due to evaporation. Since halite precipitation occurs relatively late compared to carbonate or gypsum, it was considered for modeling purposes at a $\mathrm{Cl}^{-}$concentration of $4,500 \mathrm{mmol} / \mathrm{kg}[2] . \delta^{18} \mathrm{O}_{\mathrm{H} 2 \mathrm{O}}$ results indicated that most of the lake water samples collected during both field campaigns corresponded to evaporation trends at humidity between $60 \%$ and $75 \%$ (Figure 2). Under high salt concentrations, the heavy isotope content of the residual brine would describe an increasingly trend to a certain extent, and then the tendency would reverse showing an open loop. The relatively depleted $\delta^{18} \mathrm{O}_{\mathrm{H} 2 \mathrm{O}}$ values found at high salinities may complicate the interpretation of data.

The intersection point between the isotopic evolution of surface water samples and the mixing line described by piezometer samples would represent the time at which the saline boundary layer is being developed, and therefore, the DDF. Pétrola Lake is a terminal lake where groundwater and surface water discharge. Nevertheless, when the DDF is formed, some leakage (vertical and horizontal) from the lake to the underlying aquifer occurred. This leakage favoured migration of salt to deeper parts of the aquifer [4-5]. According to the model shown in Figure 2, leakage would take place mainly from July to November 2010, coinciding with the lowest groundwater water depth in GW-12 [4]. These values are in agreement with densities from $1.24 \mathrm{~g} / \mathrm{cm}^{3}$. 


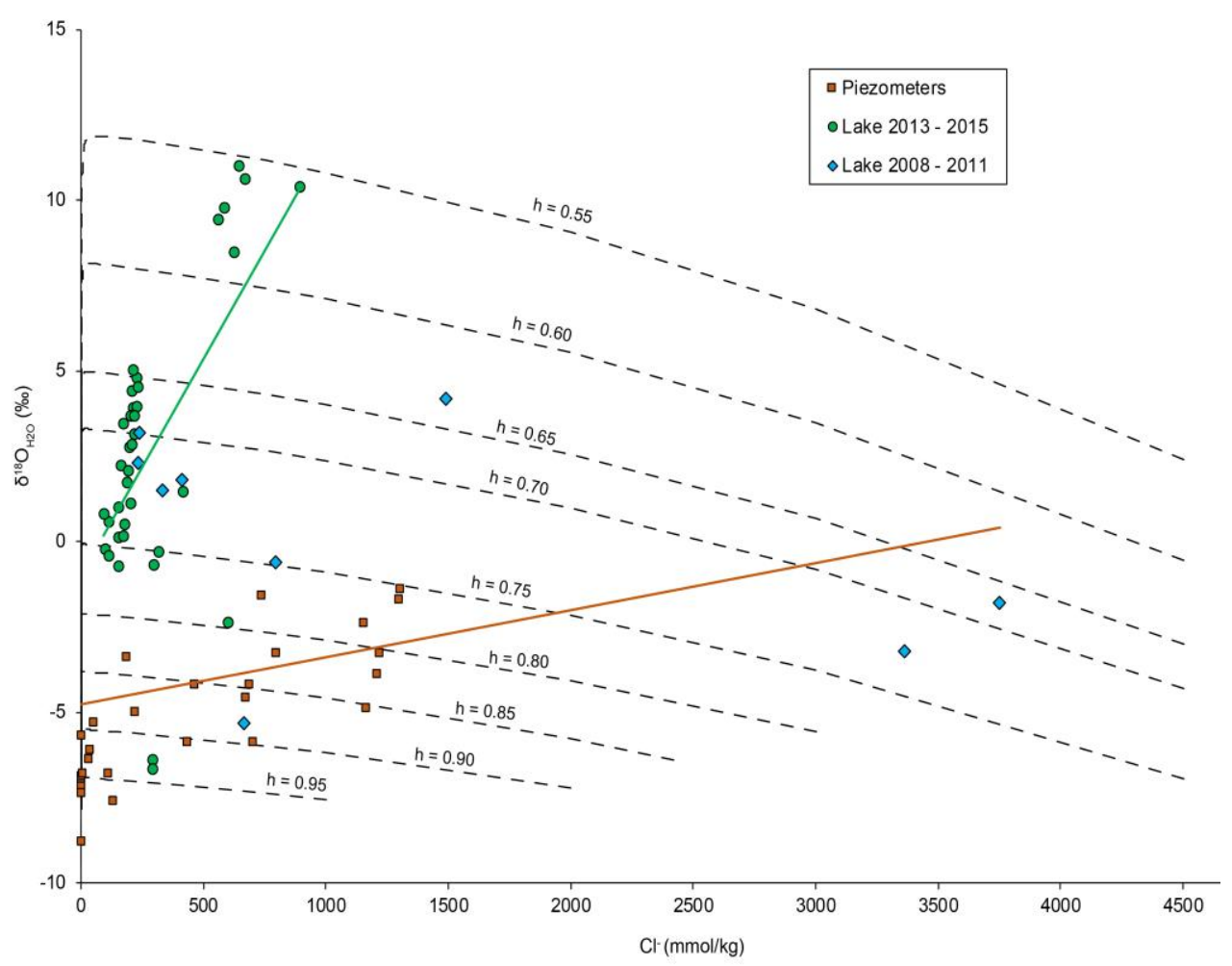

Fig. 2. $\mathrm{Cl}^{-}$versus $\delta^{18} \mathrm{O}_{\mathrm{H} 2 \mathrm{O}}$ plot showing the evolution in the isotopic composition of the residual lake water as a function of the fraction of lake water that has been lost to evaporation. Dashed lines represent the different humidity values (h) used for modeling.

\section{Conclusions}

The aim of the present research was to understand the interaction between groundwater and saline water from Pétrola Lake. This study has shown that groundwater recharge in the basin is mainly produced by Atlantic-derived precipitation. In the lake, stable isotope suggested that the loss of water occurred at humidity values between $60 \%$ and $75 \%$. Under high salt concentrations (up to $3,751 \mathrm{mmol} / \mathrm{kg}$ ), the saline boundary layer is formed. Leakage from the lake to the underlying aquifer would take place with salinities from 1.24 $\mathrm{g} / \mathrm{cm}^{3}$ by means of the density-driven flow (DDF). The findings reported here shed new light on the use of stable isotopes for understanding the role of DDF in terminal lakes.

This work was financed by the projects SBPLY/17/180501/000296 from the Castilla-La Mancha Government, and CGL2017-87216-C4-2-R from the Spanish Government.

\section{References}

1. V. I. Babkin, World Water Resources at the Beginning of the Twenty-First Century (2003)

2. I. Cartwright, S. Hall, S. Tweed, M. Leblanc, Hydrogeol. J., 17, 1991-2004 (2009)

3. C. J. Duffy, S. Al-Hassan, Water Resour. Res., 24, 1675-1688 (1988)

4. J. J. Gómez-Alday, R. Carrey, N. Valiente, N. Otero, A. Soler, C. Ayora, D. Sanz, A. Muñoz-Martín, S. Castaño, C. Recio, A. Carnicero, A. Cortijo, Sci. Total Environ, 497, 594-606 (2014)

5. N. Valiente, R. Carrey, N. Otero, A. Soler, D. Sanz, A. Muñoz-Martín, F. Jirsa, W. Wanek, J. J. Gómez-Alday, Sci. Total Environ, 631, 649-659 (2018) 
6. N. Valiente, R. Carrey, N. Otero, M. A. Gutiérrez-Villanueva, A. Soler, D. Sanz, S. Castaño, J. J. Gómez-Alday, Chem. Geol., 473, 74-89 (2017)

7. D. L. Parkhurst, C. A. J. Appelo, User's guide to PHREEQC (Version 2): A computer program for speciation, batch-reaction, one-dimensional transport, and inverse geochemical calculations (1999)

8. W. Dansgaard, Tellus 16, 436-468 (1964)

9. R. Uemura, Y. Matsui, K. Yoshimura, H. Motoyama, N. Yoshida, J. Geophys. ResAtmos., 113 (2008)

10. J. Cruz-San Julian, L. Araguas, K. Rozanski, J. Benavente, J. Cardenal, M. C. Hidalgo, S. Garcia-Lopez, J. C. Martinez-Garrido, F. Moral, M. Olias, Tellus B, 44, 226-236 (1992)

11. R. Gonfiantini, Handbook of environmental isotope geochemistry (1986) 